\title{
Crystallization Kinetics of Al-Fe and Al-Fe-Y Amorphous Alloys Produced by Mechanical Milling
}

\author{
Viet H. Nguyen, ${ }^{1}$ Oanh T. H. Nguyen, ${ }^{1}$ Dina V. Dudina, ${ }^{2,3}$ Vinh V. Le, ${ }^{4}$ and Ji-Soon Kim ${ }^{5}$ \\ ${ }^{1}$ School of Materials Science and Engineering, Hanoi University of Science and Technology, Hanoi, Vietnam \\ ${ }^{2}$ Lavrentyev Institute of Hydrodynamics SB RAS, Lavrentyev Ave. 15, Novosibirsk 630090, Russia \\ ${ }^{3}$ Novosibirsk State Technical University, K. Marx Ave. 20, Novosibirsk 630073, Russia \\ ${ }^{4}$ School of Engineering Physics, Hanoi University of Science and Technology, Hanoi, Vietnam \\ ${ }^{5}$ School of Materials Science and Engineering, University of Ulsan, San-29, Mugeo-2 Dong, Nam-Gu, Ulsan 680-749, Republic of Korea
}

Correspondence should be addressed to Viet H. Nguyen; viet.nguyenhoang@hust.edu.vn

Received 11 September 2016; Accepted 24 November 2016

Academic Editor: Edward A. Payzant

Copyright (c) 2016 Viet H. Nguyen et al. This is an open access article distributed under the Creative Commons Attribution License, which permits unrestricted use, distribution, and reproduction in any medium, provided the original work is properly cited.

In this work, the effect of a slight change in the composition of the Al-Fe amorphous alloys (from $\mathrm{Al}_{84} \mathrm{Fe}_{16}$ to $\mathrm{Al}_{82} \mathrm{Fe}_{18}$ ) and the substitution of $\mathrm{Y}$ for $\mathrm{Al}$ ( 2 at.\%) on their crystallization kinetics was studied. According to the X-ray diffraction analysis, powders of the $\mathrm{Al}_{84} \mathrm{Fe}_{16}, \mathrm{Al}_{82} \mathrm{Fe}_{18}$, and $\mathrm{Al}_{82} \mathrm{Fe}_{16} \mathrm{Y}_{2}$ alloys with a fully amorphous structure were formed after $100 \mathrm{~h}$ of mechanical milling of the mixtures of the elemental powders. The crystallization behavior of the alloys was also studied by transmission electron microscopy. Upon heating up to a temperature of the first exothermic peak, $\alpha$-Al crystals precipitated from the amorphous $\mathrm{Al}_{84} \mathrm{Fe}_{16}$ matrix. During crystallization of the $\mathrm{Al}_{82} \mathrm{Fe}_{18}$ alloy, crystals of the $\mathrm{Al}_{6} \mathrm{Fe}$ intermetallic compound formed along with $\alpha$ - $\mathrm{Al}$ crystals. Substitution of $\mathrm{Y}$ for 2 at.\% of $\mathrm{Al}$ in the $\mathrm{Al}_{82} \mathrm{Fe}_{16} \mathrm{Y}_{2}$ alloy made crystallization of the alloy more complicated: $\alpha$ - $\mathrm{Al}_{1} \mathrm{Al}_{6} \mathrm{Fe}$, and $\mathrm{Fe}{ }_{4} \mathrm{Y}$ crystals coexisted with an amorphous phase. The activation energies corresponding to the first crystallization event of the alloys were calculated using the Kissinger and Ozawa methods. The values obtained by these two methods were in good agreement with each other and the same trends of changing with the alloy composition were observed. The Avrami exponent $n$ was determined from the Johnson-Mehl-Avrami equation and showed that crystallization at the first stage is interface-controlled growth for all the three powder alloys studied.

\section{Introduction}

Amorphous aluminum-based alloys containing $\geq 80$ at.\% $\mathrm{Al}$ constitute a group of materials promising for structural applications. The main advantages of Al-based metallic glasses are high strength, low density, high elastic strain, and good corrosion resistance $[1,2]$. At the same time, irons aluminides have attracted interest due to high specific strength and excellent corrosion resistance at elevated temperatures under oxidizing, carburizing, and sulfurizing environments [3]. Although metallic glasses possess unique properties, they are metastable and tend to crystallize during continuous heating. In order to produce bulk materials retaining an amorphous structure or bulk nanostructured composites containing nanometer-sized crystals dispersed in amorphous matrices, it is necessary to determine the stability of metallic glasses during thermal treatment and evolution of their structure upon crystallization [4-6]. The driving force for crystallization of amorphous materials is the Gibbs free energy difference between the amorphous and the crystalline states. The crystallization mechanisms and the structure and composition of the crystallization products depend on the initial chemical composition of the amorphous phase and its preparation method. Studies of the crystallization behavior of amorphous alloys are necessary for evaluating their thermal stability against crystallization, determining the structure evolution paths of the amorphous alloy powders upon consolidation and for elucidating the fundamentals of the processes of the glass formation, nucleation, and growth. 

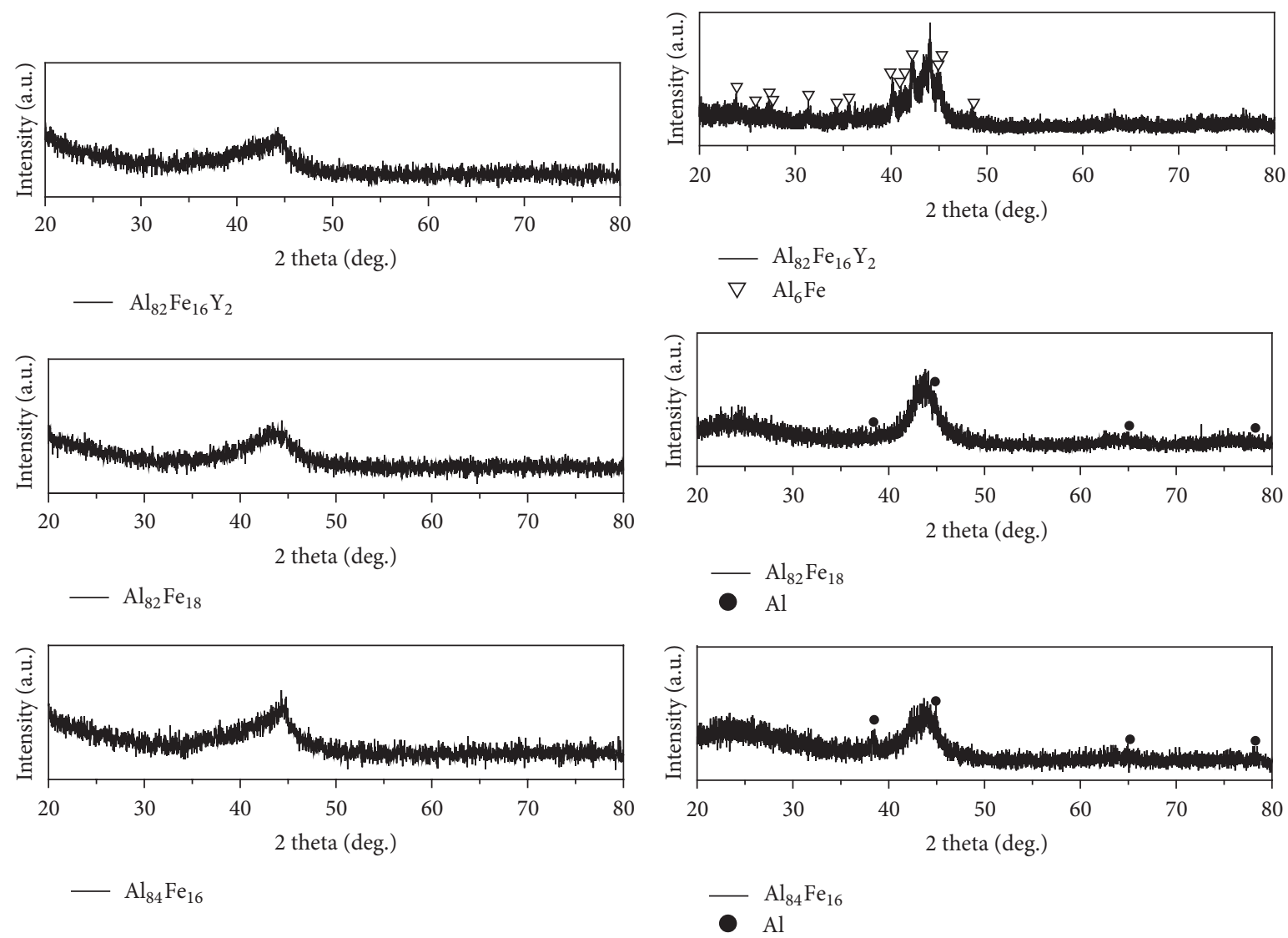

(a)

(b)

FIGURE 1: XRD patterns of the amorphous alloy powders produced by mechanical milling (a) and heated in DSC up to a temperature corresponding to completion of the first crystallization event (b).

In the present work, the kinetics of crystallization of the mechanically alloyed amorphous $\mathrm{Al}_{84} \mathrm{Fe}_{16}, \mathrm{Al}_{82} \mathrm{Fe}_{18}$, and $\mathrm{Al}_{82} \mathrm{Fe}_{16} \mathrm{Y}_{2}$ alloy powders was studied using differential scanning calorimetry (DSC), X-ray diffraction (XRD), and transmission electron microscopy (TEM).

\section{Experimental}

Amorphous alloy powders with nominal compositions of $\mathrm{Al}_{84} \mathrm{Fe}_{16}, \mathrm{Al}_{82} \mathrm{Fe}_{18}$, and $\mathrm{Al}_{82} \mathrm{Fe}_{16} \mathrm{Y}_{2}$ were synthesized via mechanical alloying [7]. Mixtures of $\mathrm{Al}, \mathrm{Fe}$, and $\mathrm{Y}$ were milled in a planetary ball mill (P100, South Korea) using hardened steel vials and hardened steel balls of $5 \mathrm{~mm}$ diameter. The rotation speed of the disc was $350 \mathrm{rpm}$ and the ball to powder weight ratio was $20: 1$. Hexane was used as a process control agent to prevent extensive agglomeration and contamination during mechanical milling. DSC was conducted using NETZSCH STA $409 \mathrm{C}$ at heating rates of $5,10,20$, and $40 \mathrm{~K} / \mathrm{min}$ to study the crystallization kinetics of the amorphous alloys. XRD was performed using RIGAKU RINT-2000 diffractometer with $\mathrm{CuK}_{\alpha}$ radiation $(\lambda=0.15405 \mathrm{~nm})$ to study the phase transformations during mechanical milling and upon subsequent heating. The microstructure of the powders was studied by TEM carried out using a JEOL JEM-2100 microscope.

\section{Results and Discussion}

The XRD analysis of the powders shows that the amorphous $\mathrm{Al}_{84} \mathrm{Fe}_{16}, \mathrm{Al}_{82} \mathrm{Fe}_{18}$, and $\mathrm{Al}_{82} \mathrm{Fe}_{16} \mathrm{Y}_{2}$ alloys formed after $100 \mathrm{~h}$ of milling. The XRD patterns of the powders (Figure 1(a)) exhibit only broad maxima between $35^{\circ}$ and $50^{\circ}(2 \theta)$ indicating that amorphization took place during milling [7]. In order to study the structural evolution during heating, the amorphous alloy powders were annealed in the DSC using continuous heating at $20 \mathrm{~K} / \mathrm{min}$ up to different temperatures to reach different crystallization events revealed by exothermic peaks and then cooled down to room temperature at $50 \mathrm{~K} / \mathrm{min}$. The DSC scans in Figure 2 show the first crystallization peaks of the three alloys recorded at 5, 10, 20 , and $40 \mathrm{~K} / \mathrm{min}$. The onset temperatures, $T_{x 1}$, of the first crystallization peak and the peak temperatures, $T_{p 1}$, of the $\mathrm{Al}_{84} \mathrm{Fe}_{16}, \mathrm{Al}_{82} \mathrm{Fe}_{18}$, and $\mathrm{Al}_{82} \mathrm{Fe}_{16} \mathrm{Y}_{2}$ alloys are presented in Table 1. It can be seen that a slight change in the composition of the $\mathrm{Al}-\mathrm{Fe}$ amorphous alloys, from $\mathrm{Al}_{84} \mathrm{Fe}_{16}$ to $\mathrm{Al}_{82} \mathrm{Fe}_{18}$, and substitution of $\mathrm{Y}$ for $\mathrm{Al}$ (2 at.\%) result in an increase of both $T_{x 1}$ and $T_{p 1}$.

Figure 1(b) shows the XRD patterns of the $\mathrm{Al}_{84} \mathrm{Fe}_{16}$, $\mathrm{Al}_{82} \mathrm{Fe}_{18}$, and $\mathrm{Al}_{82} \mathrm{Fe}_{16} \mathrm{Y}_{2}$ alloys heated in DSC up to a temperature corresponding to completion of the first crystallization event. Figures 3-5 show TEM images of the 
TABLE 1: Characteristic $T_{x 1}$ and $T_{p 1}$ temperatures of the $\mathrm{Al}_{84} \mathrm{Fe}_{16}, \mathrm{Al}_{82} \mathrm{Fe}_{18}$, and $\mathrm{Al}_{82} \mathrm{Fe}_{16} \mathrm{Y}_{2}$ alloys.

\begin{tabular}{|c|c|c|c|c|c|c|}
\hline \multirow{2}{*}{$\begin{array}{l}\text { Heating rate } \beta \\
\mathrm{K} / \mathrm{min}\end{array}$} & \multicolumn{2}{|c|}{$\mathrm{Al}_{84} \mathrm{Fe}_{16}$} & \multicolumn{2}{|c|}{$\mathrm{Al}_{82} \mathrm{Fe}_{18}$} & \multicolumn{2}{|c|}{$\mathrm{Al}_{82} \mathrm{Fe}_{16} \mathrm{Y}_{2}$} \\
\hline & $T_{x 1}, \mathrm{~K}$ & $T_{p 1}, \mathrm{~K}$ & $T_{x 1}, \mathrm{~K}$ & $T_{p 1}, \mathrm{~K}$ & $T_{x 1}, \mathrm{~K}$ & $T_{p 1}, \mathrm{~K}$ \\
\hline 5 & 618.1 & 630.3 & 630.0 & 655.6 & 640.5 & 659.9 \\
\hline 10 & 620.9 & 636.2 & 638.5 & 663.5 & 645.5 & 664.5 \\
\hline 20 & 625.2 & 640.9 & 648.9 & 670.2 & 651.7 & 669.1 \\
\hline 40 & 628.3 & 643.7 & 652.4 & 677.6 & 655.2 & 673.2 \\
\hline
\end{tabular}

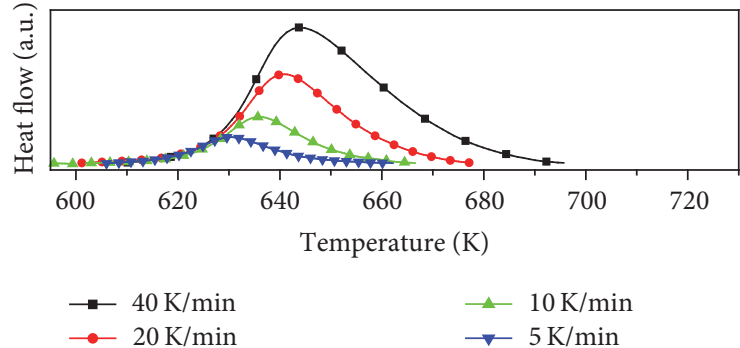

(a)

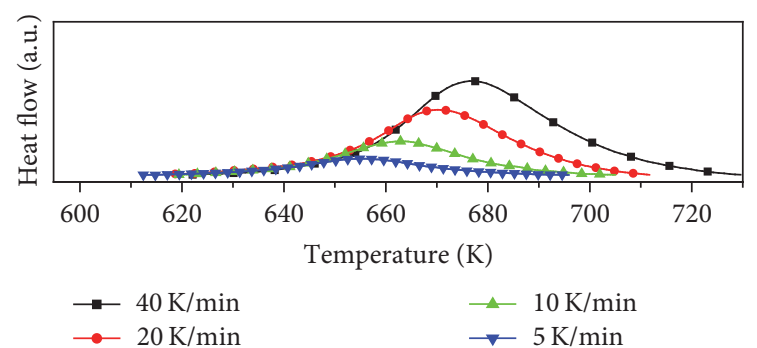

(b)

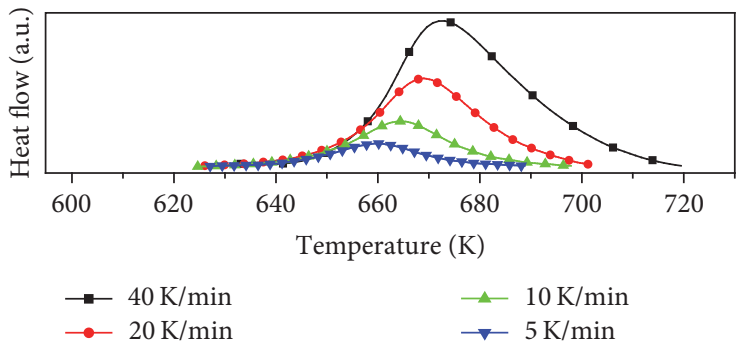

(c)

Figure 2: DSC curves obtained at different heating rates for (a) $\mathrm{Al}_{84} \mathrm{Fe}_{16}$, (b) $\mathrm{Al}_{82} \mathrm{Fe}_{18}$, and (c) $\mathrm{Al}_{82} \mathrm{Fe}_{16} \mathrm{Y}_{2}$ amorphous alloy powders.

$\mathrm{Al}_{84} \mathrm{Fe}_{16}, \mathrm{Al}_{82} \mathrm{Fe}_{18}$, and $\mathrm{Al}_{82} \mathrm{Fe}_{16} \mathrm{Y}_{2}$ alloys that experienced the first crystallization event along with selected-area diffraction (SAD) patterns. The contrast observed in the TEM images is due to separation of the alloys into solute-enriched and solute-depleted amorphous regions. The segregation of $\mathrm{Al}$ was clearly observed in the TEM images of all three alloys. The $\alpha$-Al nanocrystals then preferentially nucleated at the interface between the separated phases. In the $\mathrm{Al}_{84} \mathrm{Fe}_{16}$ alloy, only $\alpha$-Al crystals separated from the amorphous phase and had a size ranging from 10 to $30 \mathrm{~nm}$ (Figures 3(a) and $3(\mathrm{c})$ ). The SAD pattern in Figure 3(b) corresponds to an amorphous phase and that in Figure 3(d) to crystalline $\alpha$-Al. The crystallization behavior the $\mathrm{Al}_{82} \mathrm{Fe}_{18}$ was slightly different from that of the $\mathrm{Al}_{84} \mathrm{Fe}_{16}$. The $\mathrm{Al}_{82} \mathrm{Fe}_{18}$ alloy remained partially amorphous, as can be seen from Figures 4(a)-4(b). In the areas that underwent crystallization, crystals of the $\mathrm{Al}_{6} \mathrm{Fe}$ intermetallic were found together with crystals of $\alpha$-Al (Figures 4(c)-4(d)). Due to a low concentration of the intermetallic compound, the $\mathrm{Al}_{6} \mathrm{Fe}$ phase could not be detected by the XRD [7]. The concentration of the crystalline phases separated from the amorphous phase (Figure 4(a)) in the $\mathrm{Al}_{82} \mathrm{Fe}_{18}$ is higher than in the $\mathrm{Al}_{84} \mathrm{Fe}_{16}$ alloy. During heating of the $\mathrm{Al}_{82} \mathrm{Fe}_{16} \mathrm{Y}_{2}$ alloy, crystals of the $\mathrm{Fe}_{4} \mathrm{Y}$ intermetallic formed, as can be concluded from the TEM data (Figure 5).
The nucleation and growth of the $\alpha$-Al phase occurred in a manner similar to that observed during crystallization of $\mathrm{Al}_{88} \mathrm{RE}_{8} \mathrm{Ni}_{4}$ amorphous alloys [8].

It is known that the more complex the composition of the crystallites precipitating from an amorphous phase, the higher the thermal stability of the alloys [9]. From the DSC analysis of the three alloys, it can be concluded that their thermal stability increases in the following row: $\mathrm{Al}_{84} \mathrm{Fe}_{16}{ }^{-}$ $\mathrm{Al}_{82} \mathrm{Fe}_{18}-\mathrm{Al}_{82} \mathrm{Fe}_{16} \mathrm{Y}_{2}$. The thermal stability of amorphous alloys is often interpreted using the heat of mixing $\Delta H^{\text {mix }}$. The more negative the $\Delta H^{\mathrm{mix}}$, the larger the atomic constraint force and the higher the thermal stability. $\Delta H^{\mathrm{mix}}$ between Fe and $\mathrm{Al}$ (solvent) is $-11 \mathrm{~kJ} / \mathrm{mol}$, while $\Delta H^{\mathrm{mix}}$ between $\mathrm{Y}$ and $\mathrm{Al}$ (solvent) is $-38 \mathrm{~kJ} / \mathrm{mol}[10]$. As $\Delta H^{\mathrm{mix}}$ between $\mathrm{Y}$ and $\mathrm{Al}$ as a solvent is more negative, $T_{x 1}$ should increase with increasing $\mathrm{Y}$ content in the alloy.

One of the most important kinetic parameters of the crystallization process is the activation energy. The thermal stability of glassy materials is related to the activation energy values. The Kissinger [11] and Ozawa [12] methods are used to calculate the activation energy of the amorphous to crystalline phase transformation in nonisothermal crystallization processes. Kissinger proposed a method for determining the activation energy of a simple decomposition reaction 


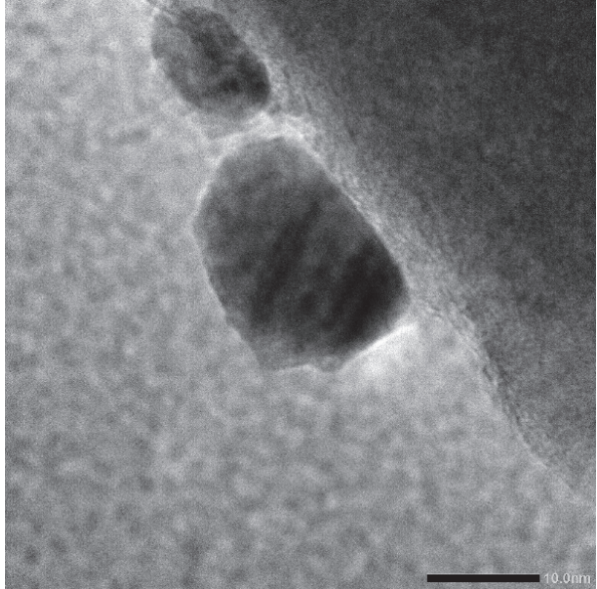

(a)

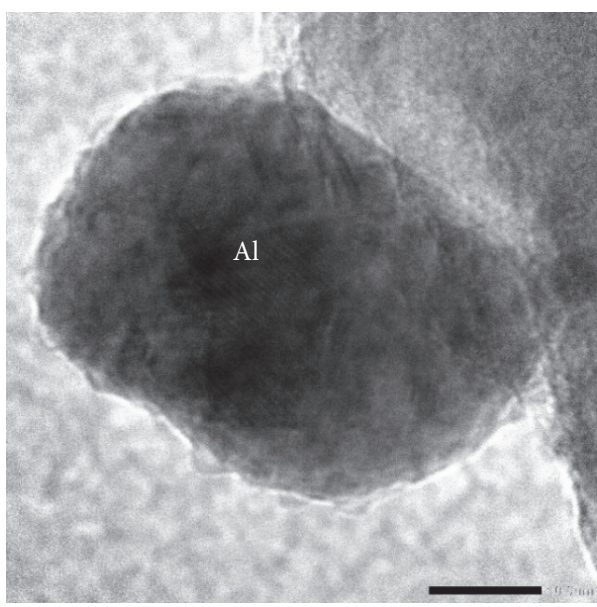

(c)

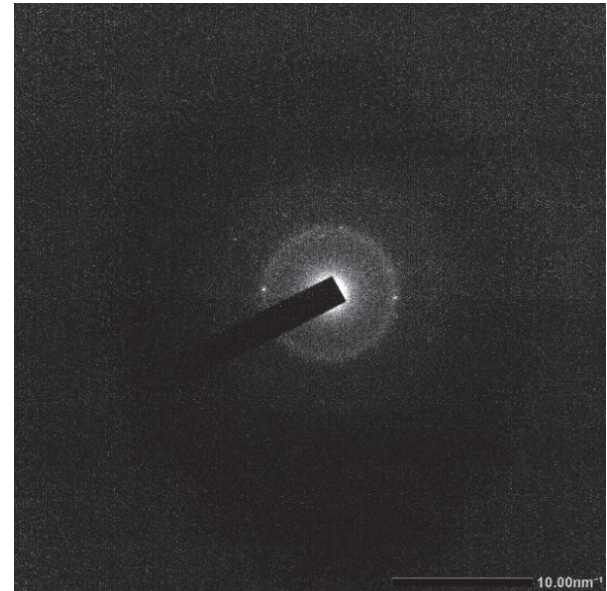

(b)

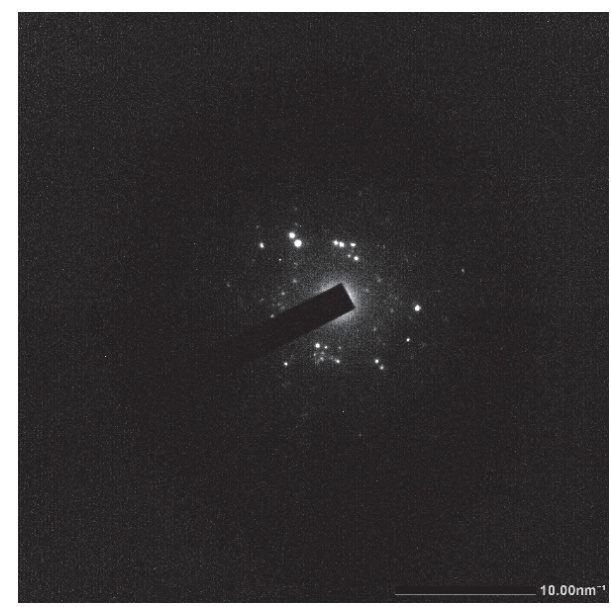

(d)

FIGURE 3: TEM images and SAD patterns of the $\mathrm{Al}_{84} \mathrm{Fe}_{16}$ alloy after the first crystallization peak: (a) bright-field TEM image of an amorphous area, (b) SAD pattern corresponding to the amorphous area, (c) bright-field TEM image of an area that had undergone crystallization, and (d) SAD pattern corresponding to (c) showing spots belonging to Al.

using differential thermal analysis scans recorded at different heating rates [9]. The heating rate of a reaction is related to the peak temperature recorded during the thermal analysis. By considering the variation of each peak temperature $T_{p}$ with the heating rate $\beta$, the activation energy $E$ can be calculated by the Kissinger method using the following equation:

$$
\ln \left(\frac{\beta}{T^{2}}\right)=-\frac{E}{R T}+\text { const, }
$$

where $E$ is the activation energy of crystallization, $T$ is the temperature of the exothermic peak, $\beta$ is the heating rate, and $R$ is the gas constant.

Figure 6 presents the plots of $\ln \left(\beta / T^{2}\right)$ versus $(1000 / T)$ and straight lines are obtained with $-E / R$ slopes for the first exothermic peak. From these data, the activation energy values $E$ for the first crystallization event of the $\mathrm{Al}_{84} \mathrm{Fe}_{16}$, $\mathrm{Al}_{82} \mathrm{Fe}_{18}$, and $\mathrm{Al}_{82} \mathrm{Fe}_{16} \mathrm{Y}_{2}$ amorphous alloy alloys were calculated to be $496.0,340.8$, and $565.0 \mathrm{~kJ} / \mathrm{mol}$, respectively.
In order to confirm the results obtained using the Kissinger method, another nonisothermal method was applied to calculate the activation energy, the Ozawa method, which uses the following equation:

$$
\ln (\beta)=-\frac{E}{R T}+\text { const, }
$$

where $\beta, T, E$, and $R$ are the heating rate, peak temperature, activation energy, and gas constant, respectively.

Figure 7 shows the plots of $\ln (\beta)$ against $1000 / T_{p}$, and $E$ was calculated from the slope of the straight lines. The values of $E$ obtained using the Ozawa equation are 506.6, 351.9, and $576.1 \mathrm{~kJ} / \mathrm{mol}$ for the $\mathrm{Al}_{84} \mathrm{Fe}_{16}, \mathrm{Al}_{82} \mathrm{Fe}_{16}$, and $\mathrm{Al}_{82} \mathrm{Fe}_{16} \mathrm{Y}_{2}$ amorphous alloy powders, respectively. The activation energies for crystallization of the $\mathrm{Al}_{84} \mathrm{Fe}_{16}, \mathrm{Al}_{82} \mathrm{Fe}_{18}$, and $\mathrm{Al}_{82} \mathrm{Fe}_{16} \mathrm{Y}_{2}$ alloys calculated by the Kissinger and Ozawa methods using the onset crystallization temperature and peak temperature of the first exothermic peak are summarized in Table 2. The values of the activation energies calculated from the Ozawa 


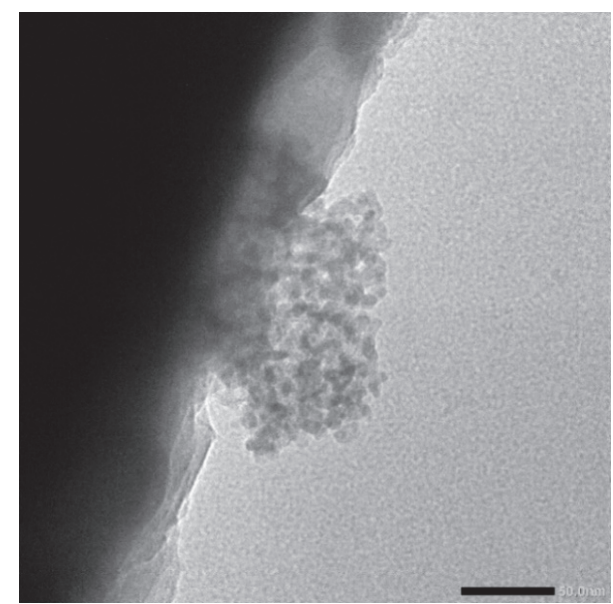

(a)

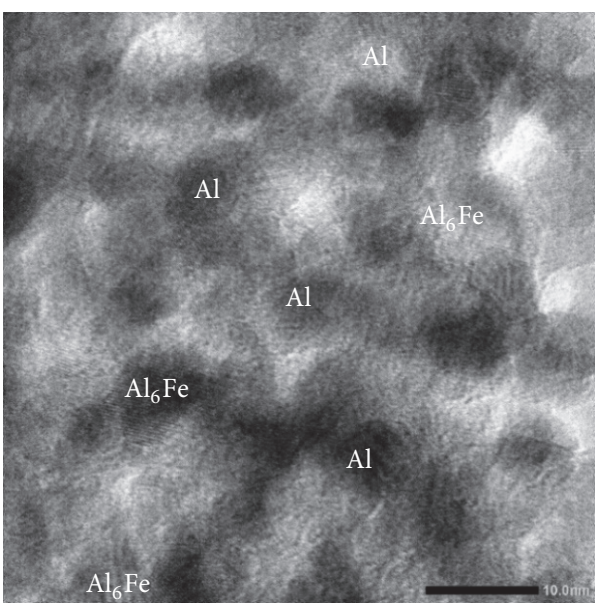

(c)

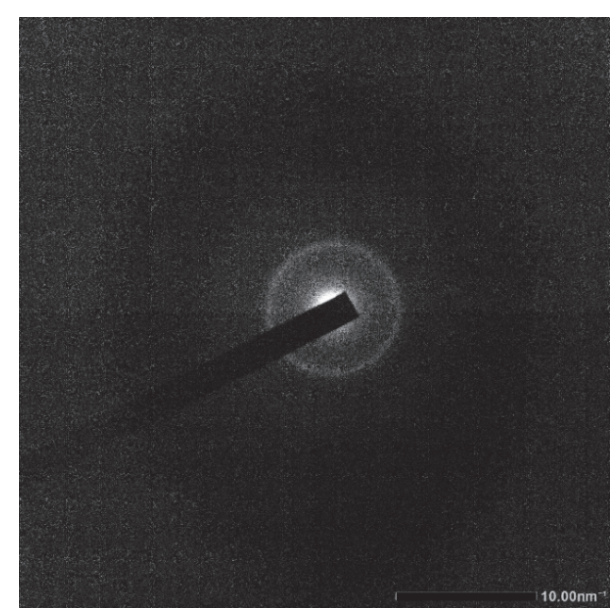

(b)

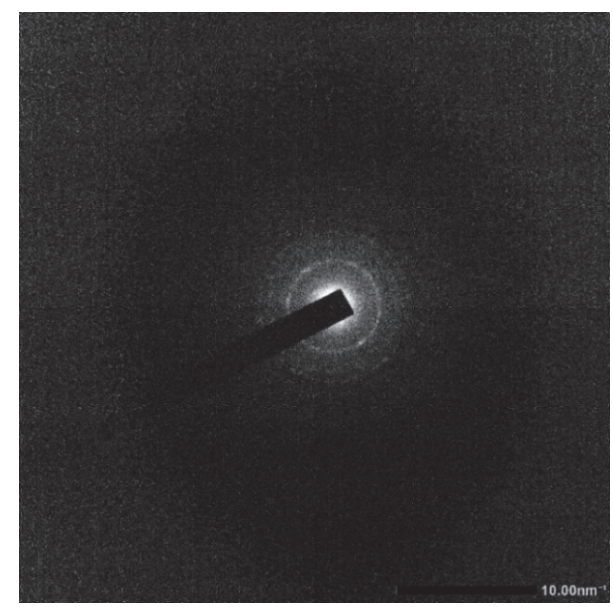

(d)

FIGURE 4: TEM images and SAD patterns of the $\mathrm{Al}_{82} \mathrm{Fe}_{18}$ alloy after the first crystallization peak: (a) bright-field TEM image of an amorphous area, (b) SAD pattern corresponding to the amorphous area, (c) bright-field TEM image of an area that had undergone crystallization, and (d) SAD pattern corresponding to (c) showing rings belonging to Al.

TABLE 2: Activation energies for crystallization of the $\mathrm{Al}_{84} \mathrm{Fe}_{16}, \mathrm{Al}_{82} \mathrm{Fe}_{18}$, and $\mathrm{Al}_{82} \mathrm{Fe}_{16} \mathrm{Y}_{2}$ amorphous alloys calculated using the onset crystallization temperature and peak temperature of the first exothermic peak.

\begin{tabular}{|c|c|c|c|c|c|c|}
\hline \multirow{3}{*}{ Methods } & \multicolumn{6}{|c|}{ Activation energy, $\mathrm{kJ} / \mathrm{mol}$} \\
\hline & \multicolumn{3}{|c|}{ Onset } & \multicolumn{3}{|c|}{ Peak 1} \\
\hline & $\mathrm{Al}_{84} \mathrm{Fe}_{16}$ & $\mathrm{Al}_{82} \mathrm{Fe}_{18}$ & $\mathrm{Al}_{82} \mathrm{Fe}_{16} \mathrm{Y}_{2}$ & $\mathrm{Al}_{84} \mathrm{Fe}_{16}$ & $\mathrm{Al}_{82} \mathrm{Fe}_{18}$ & $\mathrm{Al}_{82} \mathrm{Fe}_{16} \mathrm{Y}_{2}$ \\
\hline Kissinger & 626.8 & 284.4 & 464.9 & 496.0 & 340.8 & 565.0 \\
\hline Ozawa & 637.2 & 295.1 & 475.6 & 506.6 & 351.9 & 576.1 \\
\hline
\end{tabular}

equation are only slightly higher than those obtained from the Kissinger equation.

It is known that the onset crystallization and peak temperatures are associated with the nucleation and growth processes, respectively [13]. In the case of the $\mathrm{Al}_{84} \mathrm{Fe}_{16}$ alloy, the obtained activation energy for nucleation $(626.8 \mathrm{~kJ} / \mathrm{mol})$ is higher than the activation energy for growth $(496.0 \mathrm{~kJ} / \mathrm{mol})$, indicating that the nucleation process for the $\mathrm{Al}_{84} \mathrm{Fe}_{16}$ alloy is more difficult than the growth process. This can be seen from the TEM image in Figure 3(a): only a few crystals of
$\mathrm{Al}$ nucleated and their crystallite size was from 10 to $30 \mathrm{~nm}$. However, in the case of the $\mathrm{Al}_{82} \mathrm{Fe}_{18}$ and $\mathrm{Al}_{82} \mathrm{Fe}_{16} \mathrm{Y}_{2}$ alloys, the activation energies for nucleation (284.4 and $464.9 \mathrm{~kJ} / \mathrm{mol}$ ) are lower than the activation energies for growth (340.8 and $565.0 \mathrm{~kJ} / \mathrm{mol}$ ), indicating that the nucleation process occurs easier than the growth process. As was confirmed by TEM (Figures 4(a) and 4(c)), many crystals precipitated from the amorphous phase in the $\mathrm{Al}_{82} \mathrm{Fe}_{18}$ alloy, and the crystallite size of $\mathrm{Al}$ was less than $10 \mathrm{~nm}$. The crystallite size of $\mathrm{Al}$ in both crystallized $\mathrm{Al}_{82} \mathrm{Fe}_{18}$ and $\mathrm{Al}_{82} \mathrm{Fe}_{16} \mathrm{Y}_{2}$ alloys 


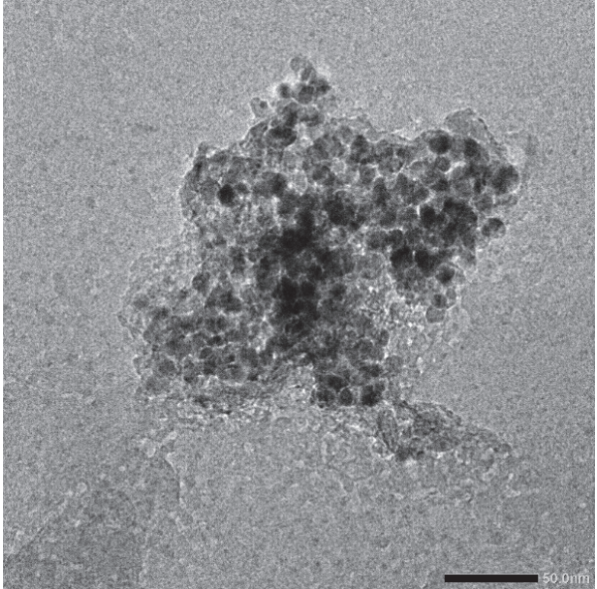

(a)

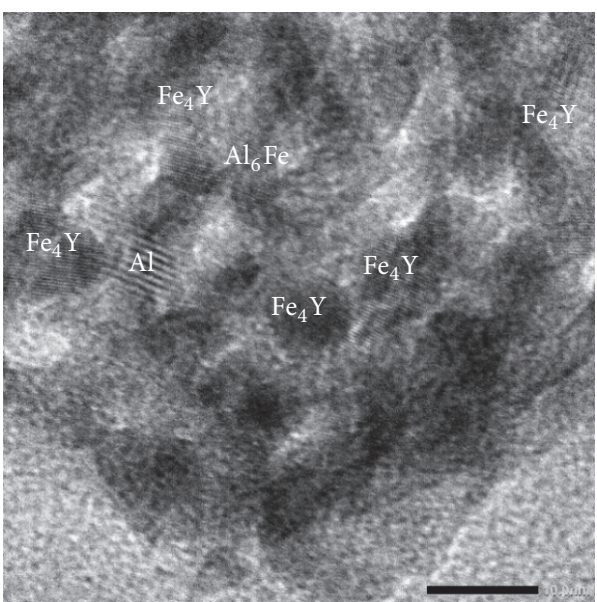

(c)

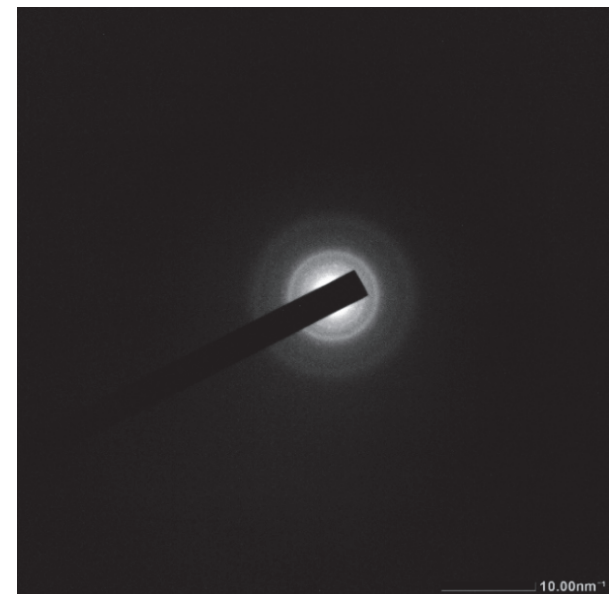

(b)

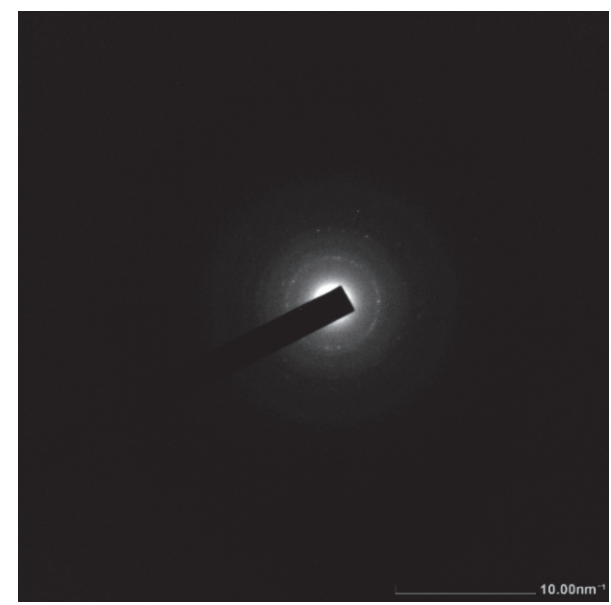

(d)

FIGURE 5: TEM images and SADP of the $\mathrm{Al}_{82} \mathrm{Fe}_{16} \mathrm{Y}_{2}$ alloy after the first crystallization peak: (a) bright-field TEM image of an amorphous area, (b) SAD pattern corresponding to the amorphous area, (c) bright-field TEM image of an area that had undergone crystallization, and (d) SAD pattern corresponding to (c) showing rings belonging to $\mathrm{Al}$.

was less than $10 \mathrm{~nm}$, which is smaller than the size of the $\mathrm{Al}$ crystallites formed in the $\mathrm{Al}_{84} \mathrm{Fe}_{16}$ alloy. This can be explained by the influence of the intermetallic phases, $\mathrm{Al}_{6} \mathrm{Fe}$ and $\mathrm{Fe}_{4} \mathrm{Y}$, which restrain growth of the $\mathrm{Al}$ crystals. An increase in the $\mathrm{Fe}$ content and partial substitution of $\mathrm{Y}$ for $\mathrm{Al}$ make the nucleation process easier (compare the values of 284.4, 464.9, and $626.8 \mathrm{~kJ} / \mathrm{mol}$ for $\mathrm{Al}_{82} \mathrm{Fe}_{18}, \mathrm{Al}_{82} \mathrm{Fe}_{16} \mathrm{Y}_{2}$, and $\mathrm{Al}_{84} \mathrm{Fe}_{16}$ alloys, resp.).

An increase in the Fe content in the alloy makes the growth process easier, while partial substitution of $\mathrm{Y}$ for $\mathrm{Al}$ alloy hinders the growth process. Yttrium has a larger atomic radius $(1.8 \AA)$ than $\mathrm{Al}(1.18 \AA)$ [10]. Larger $\mathrm{Y}$ atoms increase the potential barrier and hinder diffusion of atoms during the crystallization process of the amorphous alloys. Consequently, the activation energy increases when the substituting atoms have larger radii, implying that, in the $\mathrm{Al}_{82} \mathrm{Fe}_{16} \mathrm{Y}_{2}$ alloy, a higher energy barrier must be overcome for atomic rearrangement and diffusion of atoms in the crystallization process. The values of the apparent activation energies strongly depend on the type of the primary phase. In the $\mathrm{Al}_{84} \mathrm{Fe}_{16}$ alloy, the primary phase is $\alpha$-Al; in the $\mathrm{Al}_{82} \mathrm{Fe}_{18}$ and $\mathrm{Al}_{82} \mathrm{Fe}_{16} \mathrm{Y}_{2}$ alloys, the primary phases are the $\alpha$-Al and the intermetallic phases.

Generally, the crystallization kinetics of amorphous alloys is studied using the John-Mehl-Avrami equation [14]:

$$
x(t)=1-e^{-k \cdot t^{n}}
$$

where $x$ is the crystallization volume fraction at time $t, n$ is the Avrami exponent, and $k$ is the reaction rate constant related to the absolute temperature described by the Arrhenius equation:

$$
k=k_{o} e^{-E_{a} / R T},
$$

where $k_{o}$ is a constant, $E_{a}$ is the activation energy, $R$ is the gas constant, and $T$ is the absolute temperature. 


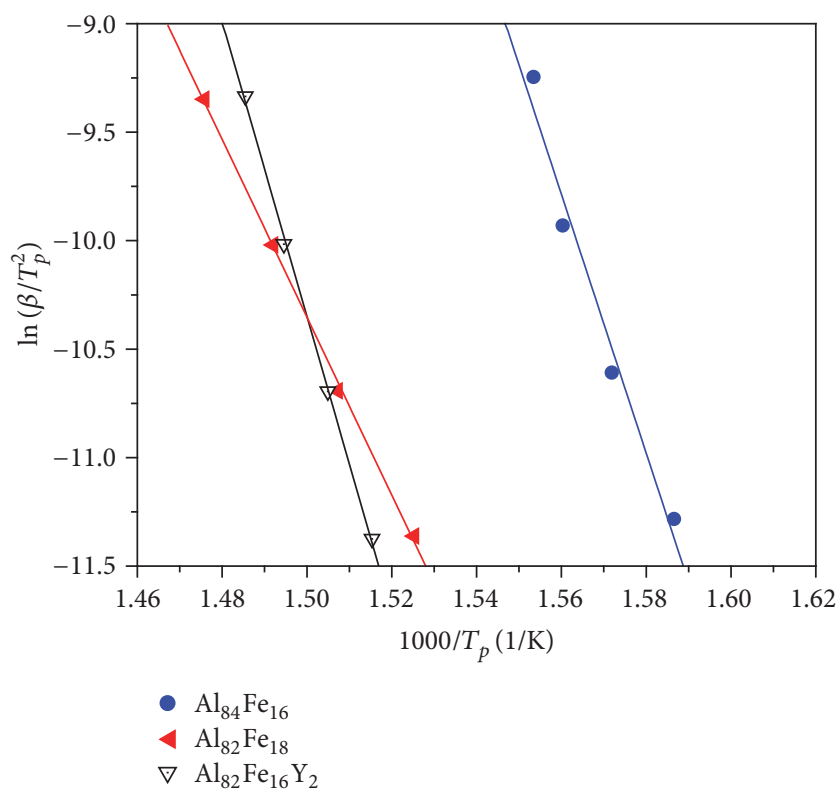

FIGURE 6: Kissinger plots for evaluating the activation energies related to the first crystallization event of the $\mathrm{Al}_{84} \mathrm{Fe}_{16}, \mathrm{Al}_{82} \mathrm{Fe}_{18}$, and $\mathrm{Al}_{82} \mathrm{Fe}_{16} \mathrm{Y}_{2}$ amorphous alloy powders.

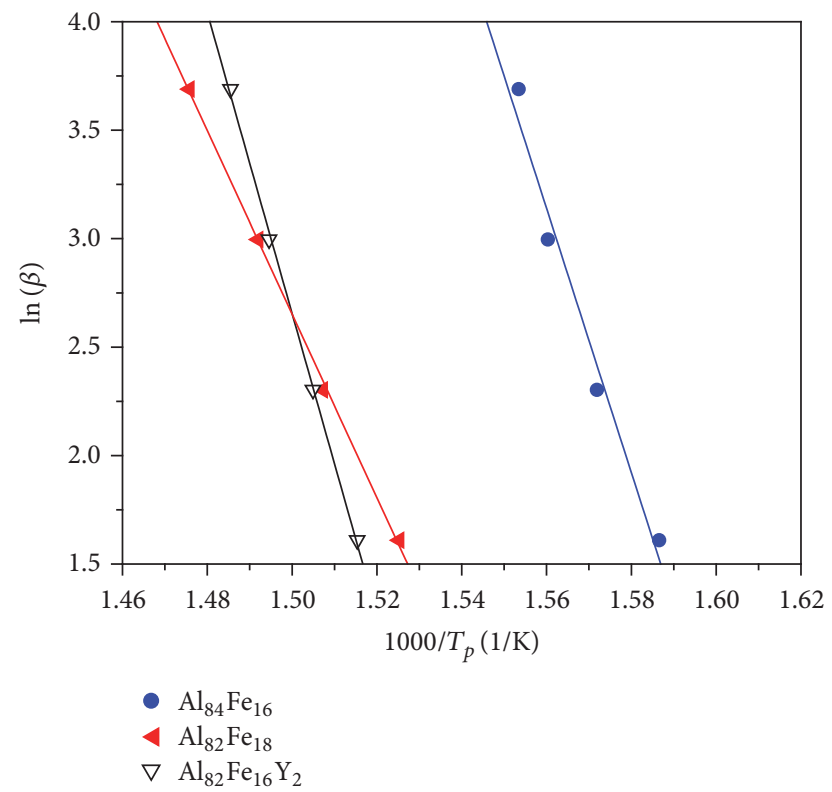

Figure 7: Ozawa plots for the evaluating the activation energies related to the first crystallization event of the $\mathrm{Al}_{84} \mathrm{Fe}_{16}, \mathrm{Al}_{82} \mathrm{Fe}_{18}$, and $\mathrm{Al}_{82} \mathrm{Fe}_{16} \mathrm{Y}_{2}$ amorphous alloy powders.

In nonisothermal DSC, the heating rate is controlled, so the temperature can be expressed as

$$
T=T_{o}+\beta \cdot t
$$

where $T_{o}$ is the starting temperature.
TABLE 3: The value of the Avrami exponent for the $\mathrm{Al}_{84} \mathrm{Fe}_{16}, \mathrm{Al}_{82} \mathrm{Fe}_{18}$, and $\mathrm{Al}_{82} \mathrm{Fe}_{16} \mathrm{Y}_{2}$ amorphous alloys.

\begin{tabular}{lcc}
\hline \multirow{2}{*}{ Alloy } & \multicolumn{2}{c}{ Avrami exponent, $n$} \\
& Eq. (7) & Eq. (8) \\
\hline $\mathrm{Al}_{84} \mathrm{Fe}_{16}$ & 0.88 & 0.94 \\
$\mathrm{Al}_{82} \mathrm{Fe}_{18}$ & 0.85 & 0.90 \\
$\mathrm{Al}_{82} \mathrm{Fe}_{16} \mathrm{Y}_{2}$ & 0.83 & 0.82 \\
\hline
\end{tabular}

Combining (3) and (4), the crystallized volume fraction can be plotted against the temperature using the following equation:

$$
x=\frac{\int_{T_{i}}^{T}(d H / d T) d T}{\int_{T_{i}}^{T_{f}}(d H / d T) d T},
$$

where $T_{i}$ and $T_{f}$ are the initial and final crystallization temperatures of the crystallization peak, respectively. Figure 8 presents the plots of the crystallized volume fraction, $x$, as a function of the temperature at different heating rates. All these curves show S-shape indicating crystallization of the amorphous alloy.

A method to determine the Avrami exponent was proposed by Ozawa [12]:

$$
\left.\frac{d \ln (-\ln (1-x))}{d \ln \beta}\right|_{T}=-n,
$$

where the crystallized volume fraction, $x$, at any selected temperature $T$ is calculated from (6).

Using equation (7) and values of $x$ at the peak temperature of the first crystallization event from Figure 8, the Avrami exponent can be determined. For the $\mathrm{Al}_{84} \mathrm{Fe}_{16}, \mathrm{Al}_{82} \mathrm{Fe}_{18}$, and $\mathrm{Al}_{82} \mathrm{Fe}_{16} \mathrm{Y}_{2}$ alloys, the Avrami exponent was calculated to be $0.88,0.85$, and 0.83 , respectively.

An alternative method [14] to obtain the Avrami exponent is through the activation energy calculated by the Kissinger method [11]:

$$
\frac{d \ln (-\ln (1-x))}{d \ln (1 / T)} \cong-\frac{n E}{R} .
$$

Plots of $\ln [-\ln (1-x)]$ versus $\ln (1 / T)$ for $x$ ranging from $15 \%$ to $85 \%$ at different heating rates are shown in Figure 9 (the Johnson-Mehl-Avrami (JMA) plots). The Avrami exponent was obtained from the slopes of these plots. The $n$ values for the $\mathrm{Al}_{84} \mathrm{Fe}_{16}, \mathrm{Al}_{82} \mathrm{Fe}_{18}$, and $\mathrm{Al}_{82} \mathrm{Fe}_{16} \mathrm{Y}_{2}$ alloys calculated by using (8) are $0.94,0.90$, and 0.82 , respectively. The values of the Avrami exponent $n$ obtained by these two methods are listed in Table 3.

The Avrami exponent $n$ provides information on the nucleation and growth mechanism of new crystalline grains during the phase transition. The values of the Avrami exponent for the $\mathrm{Al}_{84} \mathrm{Fe}_{16}, \mathrm{Al}_{82} \mathrm{Fe}_{18}$, and $\mathrm{Al}_{82} \mathrm{Fe}_{16} \mathrm{Y}_{2}$ alloys are below 1 and close to 1 . The Avrami exponent $n$ (originally expected to be $n=1,2,3,4[14,15]$ ) can also have noninteger fractional values corresponding to physically complex 


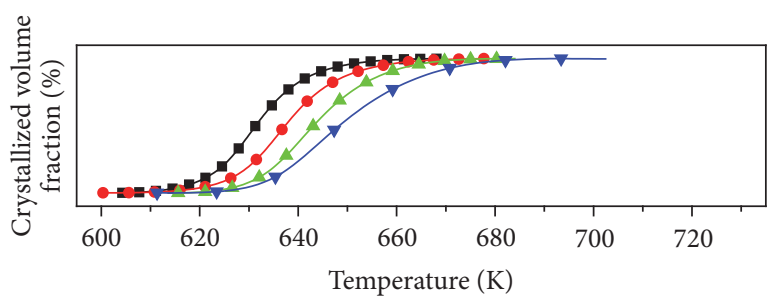

(a)

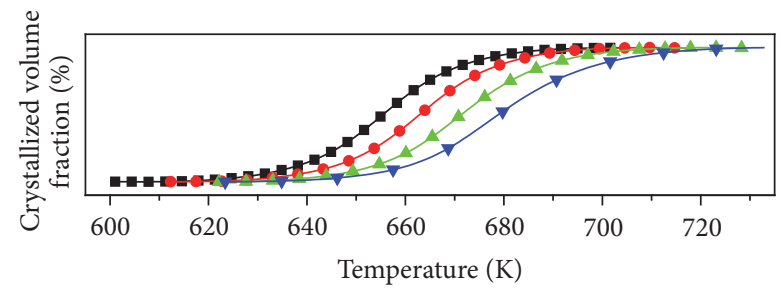

(b)

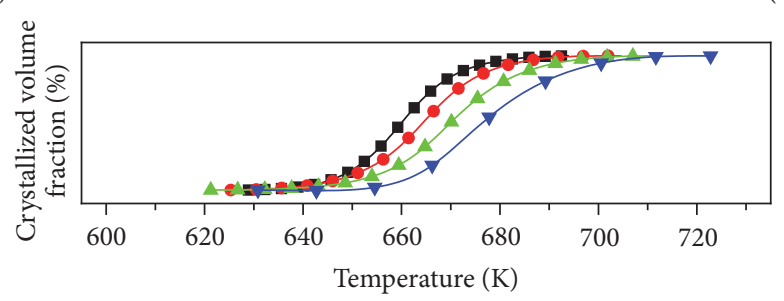

(c)

Figure 8: Crystallized volume fraction $x$ for (a) $\mathrm{Al}_{84} \mathrm{Fe}_{16}$, (b) $\mathrm{Al}_{82} \mathrm{Fe}_{18}$, and (c) $\mathrm{Al}_{82} \mathrm{Fe}_{16} \mathrm{Y}_{2}$ alloys at different heating rates.
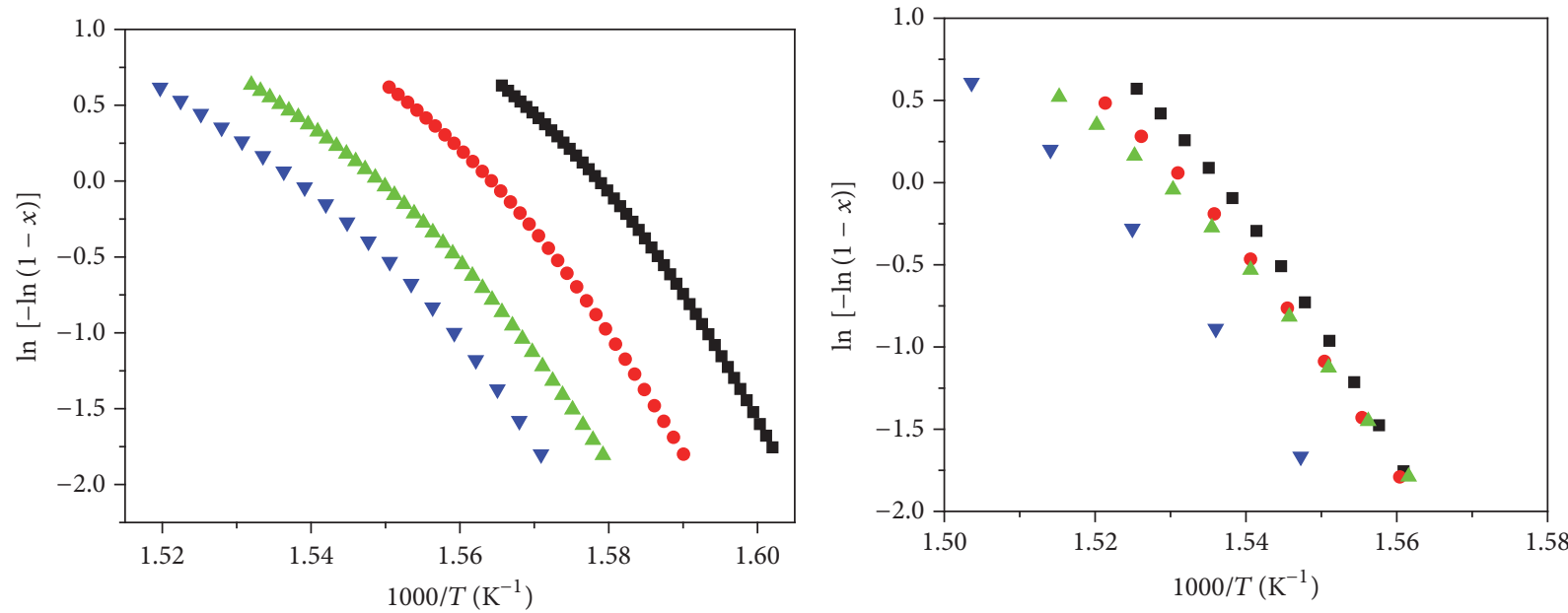

- $5 \mathrm{~K} / \mathrm{min}$

$\Delta 20 \mathrm{~K} / \mathrm{min}$

$10 \mathrm{~K} / \mathrm{min}$

v $40 \mathrm{~K} / \mathrm{min}$

(a)
- $5 \mathrm{~K} / \mathrm{min}$

- $10 \mathrm{~K} / \mathrm{min}$

- $20 \mathrm{~K} / \mathrm{min}$

> $40 \mathrm{~K} / \mathrm{min}$

(b)

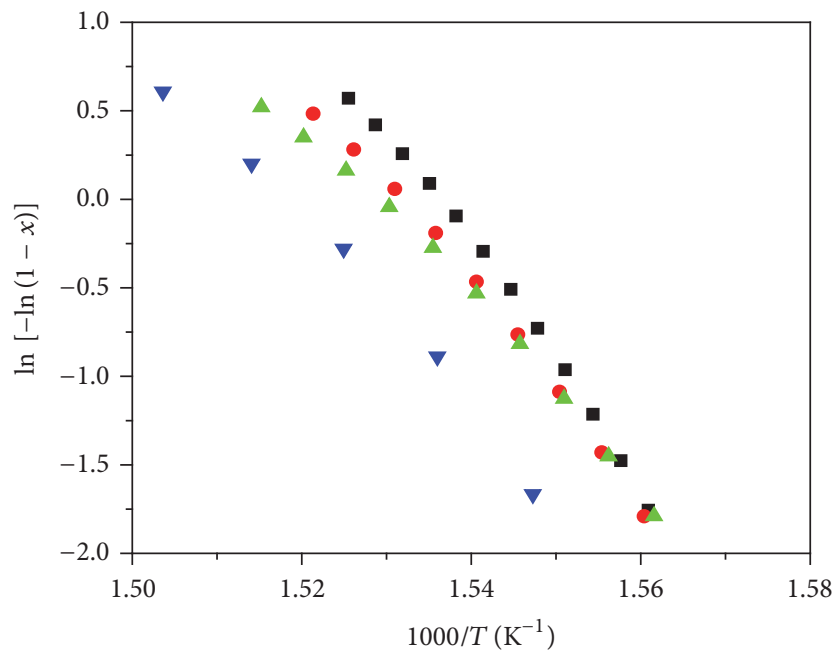

- $5 \mathrm{~K} / \mathrm{min}$

- $10 \mathrm{~K} / \mathrm{min}$

- $20 \mathrm{~K} / \mathrm{min}$

$\nabla 40 \mathrm{~K} / \mathrm{min}$

(c)

Figure 9: JMA plots for crystallization of (a) $\mathrm{Al}_{84} \mathrm{Fe}_{16}$, (b) $\mathrm{Al}_{82} \mathrm{Fe}_{18}$, and (c) $\mathrm{Al}_{82} \mathrm{Fe}_{16} \mathrm{Y}_{2}$ amorphous alloys at different heating rates. 
microstructural evolution. The obtained values of $n$ suggest that the transformation at the first stage includes structural changes and homogeneous reactions with the interfacecontrolled growth $[15,16]$. These crystallization mechanisms are consistent with the conclusions drawn from the data obtained by TEM.

\section{Conclusions}

In this study, the effect of the $\mathrm{Fe} / \mathrm{Al}$ ratio and $\mathrm{Y}$ substitution for $\mathrm{Al}$ in the $\mathrm{Al}-\mathrm{Fe}$ and $\mathrm{Al}-\mathrm{Fe}-\mathrm{Y}$ amorphous alloys $\left(\mathrm{Al}_{84} \mathrm{Fe}_{16}\right.$, $\mathrm{Al}_{82} \mathrm{Fe}_{18}$, and $\mathrm{Al}_{82} \mathrm{Fe}_{16} \mathrm{Y}_{2}$ ) on their crystallization kinetics was investigated. Higher crystallization onset temperatures of the first crystallization peak with an increase in the Fe content and substitution of $\mathrm{Y}$ for $\mathrm{Al}$ indicated that the thermal stability of the alloys was improved. TEM studies showed that only $\alpha$-Al crystals precipitated from the amorphous phase in the $\mathrm{Al}_{84} \mathrm{Fe}_{16}$ alloy. An increase in the Fe content resulted in the formation of the crystals of the $\mathrm{Al}_{6} \mathrm{Fe}$ intermetallic, as was concluded from the TEM analysis of the $\mathrm{Al}_{82} \mathrm{Fe}_{18}$ alloy. There were three crystalline phases precipitating from the amorphous phase in the $\mathrm{Al}_{82} \mathrm{Fe}_{16} \mathrm{Y}_{2}$ alloy: $\alpha$-Al, $\mathrm{Al}_{6} \mathrm{Fe}$, and $\mathrm{Fe}_{4} \mathrm{Y}$. The values of the activation energies for the first crystallization stage of the amorphous alloys were calculated using the Kissinger and Ozawa methods. These two methods gave values that were in good agreement with each other and revealed the same trends of the changes of the activation energy with the alloy composition. The activation energy for nucleation increases in the $\mathrm{Al}_{82} \mathrm{Fe}_{18}-\mathrm{Al}_{82} \mathrm{Fe}_{16} \mathrm{Y}_{2}-\mathrm{Al}_{84} \mathrm{Fe}_{16}$ order. The activation energy for growth increases when two $\mathrm{Y}$ atoms substitute for two $\mathrm{Al}$ atoms and decreases when two $\mathrm{Fe}$ atoms substitute for two $\mathrm{Al}$ atoms in the $\mathrm{Al}_{84} \mathrm{Fe}_{16}$ amorphous alloy. The Avrami parameter for the first crystallization peak of all three amorphous alloys was lower than 1, suggesting that the transformation was interface-controlled growth, which was consistent with the results of the TEM analysis. It was found that a small change in the radius of the substituting element influences the structure of the crystallization products.

\section{Competing Interests}

The authors declare that they have no competing interests.

\section{Acknowledgments}

This research is funded by Vietnam National Foundation for Science and Technology Development (NAFOSTED) under Grant no. 103.02-2012.19.

\section{References}

[1] A. Inoue, "Amorphous, nanoquasicrystalline and nanocrystalline alloys in Al-based systems," Progress in Materials Science, vol. 43 , no. 5, pp. 365-520, 1998.

[2] J. H. Perepezko and R. J. Hebert, "Amorphous aluminum alloys-synthesis and stability," JOM, vol. 54, no. 3, pp. 34-39, 2002.

[3] S. C. Deevi, V. K. Sikka, and C. T. Liu, "Processing, properties, and applications of nickel and iron aluminides," Progress in
Materials Science, vol. 42, no. 1-4, pp. 177-192, 1997.

[4] S. Scudino, K. B. Surreddi, H. V. Nguyen et al., "High-strength $\mathrm{Al}_{87} \mathrm{Ni}_{8} \mathrm{La}_{5}$ bulk alloy produced by spark plasma sintering of gas atomized powders," Journal of Materials Research, vol. 24, no. 9, pp. 2909-2916, 2009.

[5] P. P. Choi, J. S. Kim, O. T. H. Nguyen, and Y. S. Kwon, " $\mathrm{Ti}_{50} \mathrm{Cu}_{25} \mathrm{Ni}_{20} \mathrm{Sn}_{5}$ bulk metallic glass fabricated by powder consolidation," Materials Letters, vol. 61, no. 23-24, pp. 45914594, 2007.

[6] K. B. Surreddi, S. Scudino, M. Sakaliyska, K. G. Prashanth, D. J. Sordelet, and J. Eckert, "Crystallization behavior and consolidation of gas-atomized $\mathrm{Al}_{84} \mathrm{Gd}_{6} \mathrm{Ni}_{7} \mathrm{Co}_{3}$ glassy powder," Journal of Alloys and Compounds, vol. 491, no. 1-2, pp. 137-142, 2010.

[7] N. H. Viet, N. T. H. Oanh, P. N. D. Quynh, T. Q. Lap, and J.-S. Kim, "Thermal stability of amorphous Al-Fe-Y prepared by mechanical alloying," Materials Science Forum, vol. 804, pp. 271-274, 2015.

[8] T. K. Croat, A. K. Gangopadhyay, and K. F. Kelton, "Crystallization in $\mathrm{Al}_{88} \mathrm{RE}_{8} \mathrm{Ni}_{4}$ glass-forming alloys," Philosophical Magazine A: Physics of Condensed Matter, Structure, Defects and Mechanical Properties, vol. 82, no. 12, pp. 2483-2497, 2002.

[9] L.-C. Zhang, "Chapter 8-crystallization behavior and control of amorphous alloys," in Advances in Crystallization Processes, Y. Mastai, Ed., p. 185, InTech, Rijeka, Croatia, 2012.

[10] A. Takeuchi and A. Inoue, "Classification of bulk metallic glasses by atomic size difference, heat of mixing and period of constituent elements and its application to characterization of the main alloying element," Materials Transactions, vol. 46, no. 12, pp. 2817-2829, 2005.

[11] H. E. Kissinger, "Reaction kinetics in differential thermal analysis," Analytical Chemistry, vol. 29, no. 11, pp. 1702-1706, 1957.

[12] T. Ozawa, "Kinetics of non-isothermal crystallization," Polymer, vol. 12, no. 3, pp. 150-158, 1971.

[13] H.-R. Wang, Y.-L. Gao, G.-H. Min, X.-D. Hui, and Y.-F. Ye, "Primary crystallization in rapidly solidified $\mathrm{Zr}_{70} \mathrm{Cu}_{20} \mathrm{Ni}_{10}$ alloy from a supercooled liquid region," Physics Letters, Section A: General, Atomic and Solid State Physics, vol. 314, no. 1-2, pp. 8187, 2003.

[14] M. Avrami, "Kinetics of phase change. I: general theory," The Journal of Chemical Physics, vol. 7, no. 12, pp. 1103-1112, 1939.

[15] J. W. Christian, The Theory of Transformations in Metals and Alloys, Pergamon, Amsterdam, The Netherlands, 1975.

[16] I. Gutzow, S. Todorova, and N. Jordanov, "Kinetics of chemical reactions and phase transitions at changing temperature: general reconsiderations and a new approach," Bulgarian Chemical Communications, vol. 42, no. 2, pp. 79-102, 2010. 

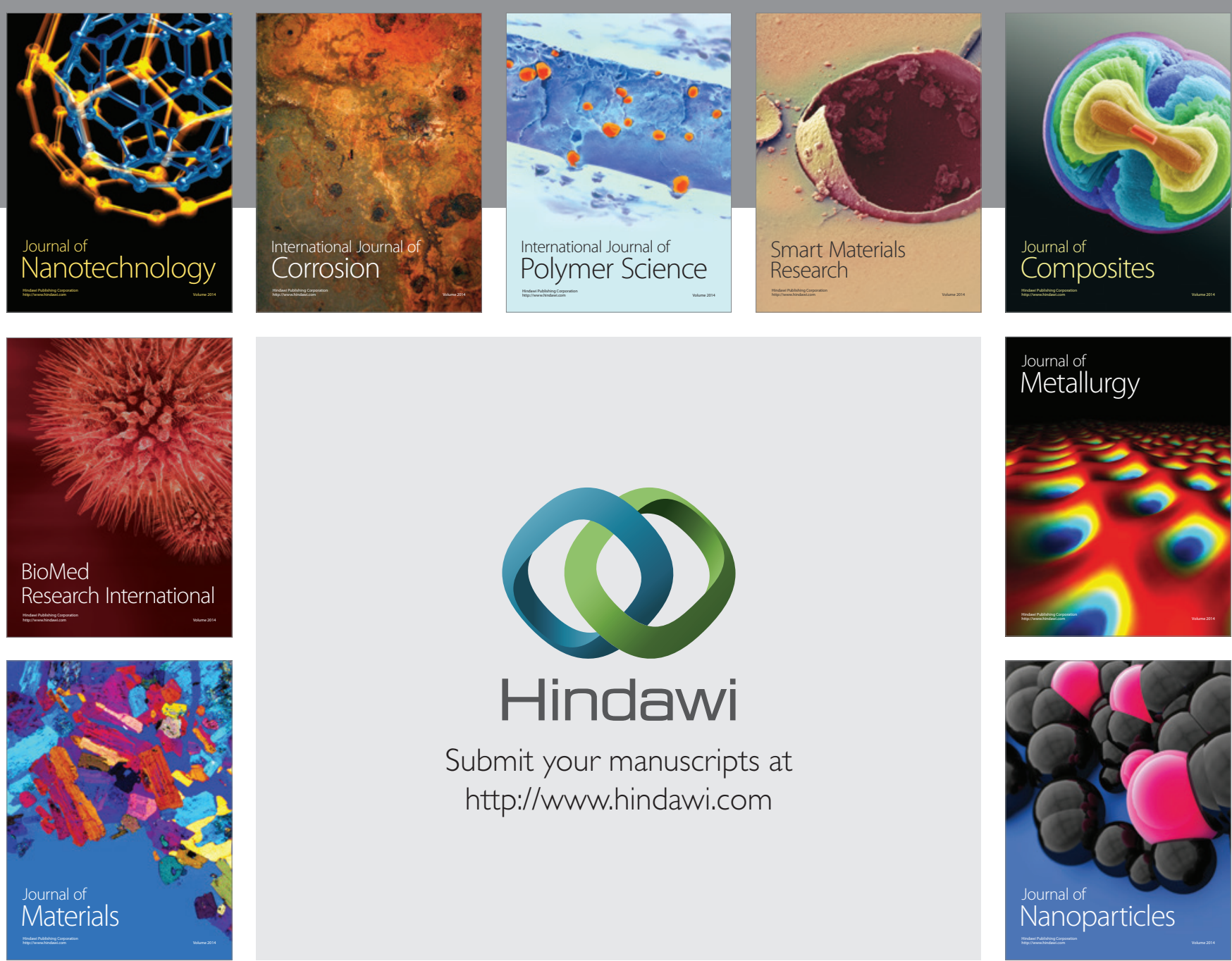

\section{Hindawi}

Submit your manuscripts at

http://www.hindawi.com

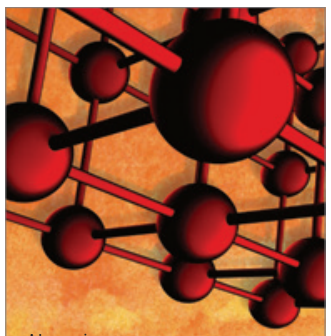

Materials Science and Engineering
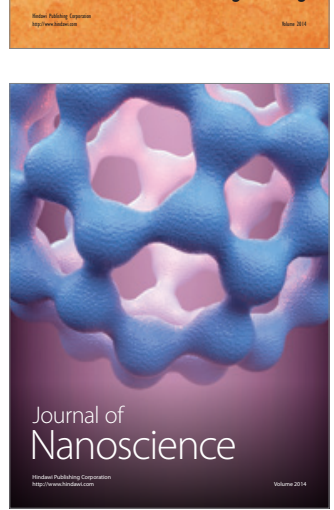
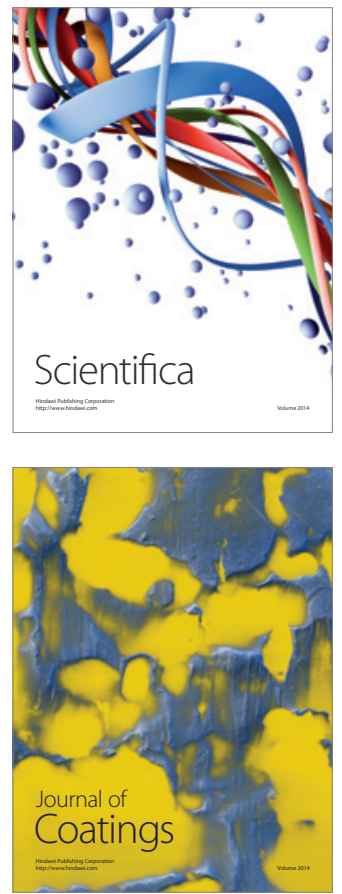
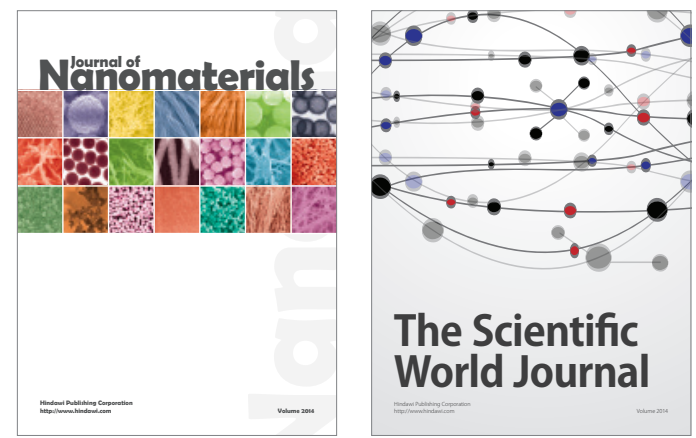

The Scientific World Journal
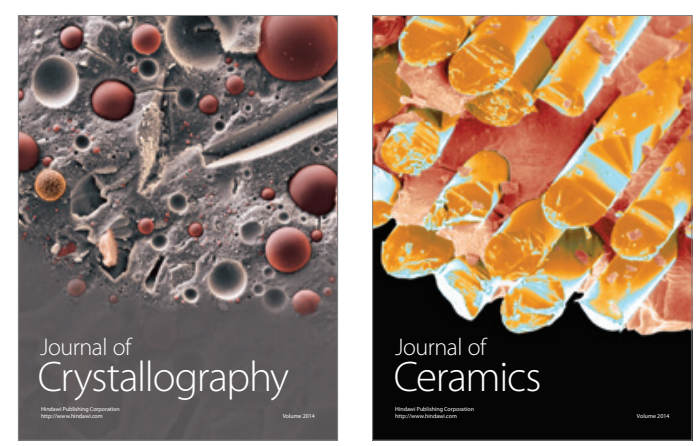
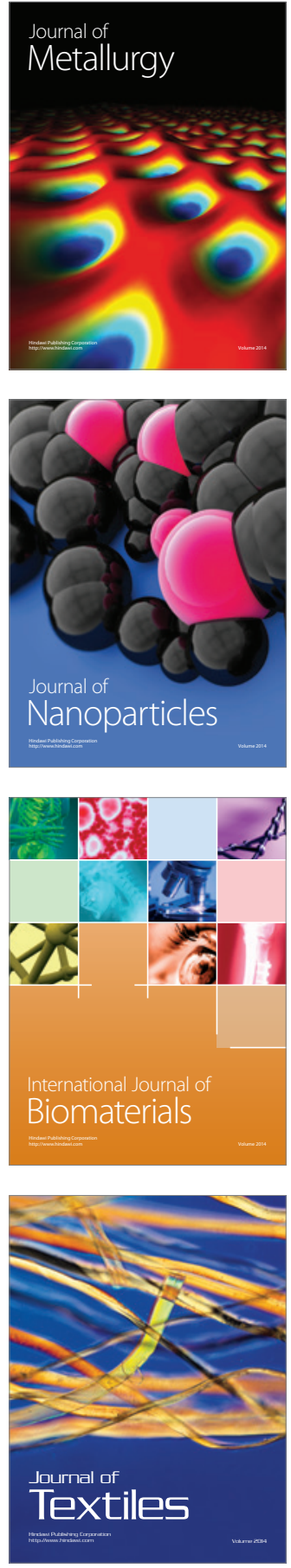